\title{
JPSE
}

(Journal of Physical Science and Engineering)

\section{Struktur dan Sifat Mekanis Film Bacterial Cellulose dengan Disintegrasi Mekanis}
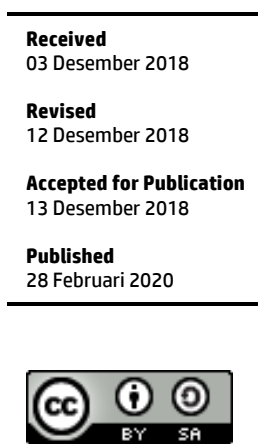

This work is licensed under a Creative Commons Attribution ShareAlike 4.0 International License.

\author{
M Muhajir ${ }^{1}$, H Suryanto $^{1^{*}}$, dan A Larasati ${ }^{1}$ \\ 1. Teknik Mesin, Pascasarjana, Universitas Negeri Malang, Jl. Semarang No. 5, Malang, 65145, \\ Indonesia \\ *E-mail: heru.suryanto.ft@um.ac.id
}

\begin{abstract}
The film structure was greatly affected by the mechanical properties of Bacterial Cellulose (BC). An engineering effort on the Bacterial Cellulose Fibers (BCF) structure was changing the size and distribution of BCF through the mechanical disintegrator process using a High Speed Blender (HSB). This study aimed to show the effect of disintegrator on the structure and mechanical properties of BCF film. In this study, the BCF was synthesized by fermentation of pineapple peel waste with incubation of Acetobacter xylinum (A. xylinum) for 14 days. BC pellicle was soaked by using $1 \% \mathrm{NaOH}$ for 24 hours then distrusted using the HSB with code speed variation of L (18000 rpm), M (21000 rpm), and H (26000 rpm) for $5 \mathrm{~min}$. Then film formed by a casting method and dried in the oven at a temperature of $60^{\circ} \mathrm{C}$ for 8 hours. The study result showed that the morphology of BCF formed pores, the crystallinity decreased so the tensile strength was decreased by $94 \%$. The results of this study are expected to provide engineering information on the BCF structure potentially for filters and for sensors.
\end{abstract}

Keywords: Bacterial Cellulose, structure, disintegrator, mechanical properties, crystallinity.

\section{Abstrak}

Struktur film sangat berpengaruh terhadap sifat mekanis dari Bacterial Cellulose (BC). Upaya merekayasa struktur Bacterial Cellulose Fibers (BCF) adalah dengan mengubah ukuran dan distribusi serat $\mathrm{BC}$ melalui proses disintegrator mekanis menggunakan High Speed Blender (HSB). Penelitian ini bertujuan untuk mengetahui pengaruh disintegrasi terhadap struktur dan sifat mekanis film BCF. Metode yang digunakan dalam penelitian ini adalah sintesis BCF dari fermentasi limbah kulit nanas dengan inkubasi bakteri Acetobacter xylinum (A. xylinum) selama 14 hari. Serat $\mathrm{BC}$ direndam dengan $\mathrm{NaOH} 1 \%$ selama 24 jam kemudian dihaluskan dengan HSB kode variasi kecepatan L (18000 rpm), M (21000 rpm), dan H (26000 rpm) selama 5 menit. Film dibentuk dengan metode casting dan dikeringkan menggunakan oven pada suhu $60^{\circ} \mathrm{C}$ selama 8 jam. Hasil penelitian menunjukkan morfologi BCF menjadi berpori dengan kristalinitasnya menurun sehingga kekuatan tarik film juga menurun sebesar $94 \%$. Hasil penelitian ini diharapkan memberikan informasi rekayasa struktur BCF berpotensi untuk filter dan maupun untuk sensor.

Kata Kunci: Bacterial Cellulose, struktur, disintegrator, sifat mekanis, kristalinitas.

\section{Pendahuluan}

Selulosa merupakan materi dari alam yang paling berlimpah di bumi dengan densitas yang rendah [1]. Secara global, diperkirakan $10^{10}-10^{11}$ ton selulosa diekstraksi dari tanaman ataupun limbahnya setiap tahun [2]. Selulosa pada umum diisolasi dari sumber alami yaitu kapas [3], bambu, Populus Tremula [4], kayu [5], dan serat rami [6]. Selulosa dari tanaman mengandung hemiselulosa, lignin, dan kotoran lainnya sehingga dalam prosesnya memerlukan perlakuan kimia [7]. Serat selulosa tanaman memiliki kandungan kimia yang bermacam-macam, sehingga diperlukan proses yang lebih lama dan bervariasi dengan biaya yang lebih tinggi untuk ekstraksi nanoselulosa dari serat selulosa tanaman. Ekstraksi selulosa tumbuhan membutuhkan sumber tanaman yang banyak sehingga memicu perambahan hutan 
yang dapat berujung pada peningkatan pemanasan global. Untuk itu, diperlukan alternatif sumber selulosa yang lain yaitu melalui proses fermentasi oleh bakteri.

A. xylinum adalah bakteri yang biasa digunakan untuk menghasilkan $\mathrm{BC}$ dengan jaringan tridimensional berpori dalam matriks cair [8]. Produksi BC lebih murah dan lebih sederhana daripada isolasi dari serat alami dengan komposisi kimianya yang lebih beragam. Produk BC yang paling banyak dibuat yaitu dari air kelapa [9] namun juga menggunakan ekstrak buah [7]. Pada tahun 2015 Indonesia sebagai pengekspor ke-3 di Asia Tenggara untuk olahan nanas dengan kapasitas produksi mencapai 1,73 juta ton per tahun [10]. Tentunya akan menghasilkan limbah kulit nanas yang cukup besar. Tidak hanya itu kulit buah nanas juga dapat dibuat menjadi sirup dan diekstraksi cairannya untuk kebutuhan pakan ternak [10]. Upaya membuat BC dari kulit nanas telah dilakukan penelitian yang diinkubasi dalam kultur statis dengan bakteri Gluconobacter xylinum [11]. Oleh karena itu, kulit nanas merupakan peluang untuk dikembangkan sebagai sumber karbon dan nitrogen untuk bahan baku selulosa yang dihasilkan oleh bakteri.

BC memiliki kekuatan mekanis, kristalinitas, kemurnian yang tinggi, dan biokompatibilitas yang baik sehingga banyak diaplikasikan juga pada bidang biomedis [12]. Selain itu, juga digunakan untuk komponen membran audio [13], kertas elektronik [14], dan dioda yang dapat memancarkan cahaya organik yang fleksibel [15]. BC juga diaplikasikan sebagai pengisi dalam komposit, di samping juga sebagai matriks komposit dengan penambahan penguat nanopartikel $\mathrm{Fe}_{3} \mathrm{O}_{4}$ [16], poliester alifatik [17], polikaprolakton [8], dan akrilik [18]. Dengan begitu banyak potensi penggunaan bahan BC, maka perlu untuk mencari cara yang tepat untuk menghasilkan partikel $\mathrm{BC}$ berukuran nano dengan proses yang lebih ekonomis.

Film selulosa dapat diproduksi menggunakan perlakuan mekanis yang dikombinasikan dengan perlakuan kimia, enzimatik, dan mekanis [19]. Metode mekanis yang telah digunakan untuk membuat serat selulosa diantaranya dengan proses grinding [20], cryocrushing [21] microfluidization [22], refining [23], dan High Pressure Homogenizer (HPH) [1], [21], [22]. Setiap metode dapat mempengaruhi film selulosa fiber tergantung pada bahan baku, metode perlakuan dan proses disintegrasi [26]. Proses disintegrasi mekanis menjadi BC menarik untuk aplikasi komersial karena proses disintegrasi selulosa menghasilkan rekayasa perubahan pada ukuran serat selulosa sehingga memengaruhi topografi dan struktur dari BCF. Oleh sebab itu, penelitian ini bertujuan untuk menganalisis pengaruh dari kecepatan High Speed Blender (HSB) terhadap struktur dan sifat mekanis dari BCF.

\section{Metode Penelitian}

2.1 Bahan

A. xylinum isolat lokal digunakan untuk produksi BC dipasok dari Laboratorium Bidang Mikrobiologi, Fakultas Matematika dan Ilmu Pengetahuan Alam (FMIPA), Universitas Negeri Malang, Jawa Timur, Indonesia. Ekstrak kulit nanas matang digunakan sebagai media fermentasi bakteri serta asam asetat $\left(\mathrm{CH}_{3} \mathrm{COOH}\right)$ (merek Dixi $25 \%$ ), amonium sulfat $\left(\mathrm{NH}_{4}\right) 2 \mathrm{SO}_{4}$ (merek Emsure 1.01217.100), dan natrium hidroksida $(\mathrm{NaOH})(\mathrm{SAP}$ chemicals $98 \%$ ) digunakan dalam proses sintesis selulosa bakteri.

\subsection{Sintesis Selulosa Bakteri}

Dalam penelitian ini, BC dibuat dengan menggunakan prosedur [11]. A. xylinum digunakan untuk produksi selulosa bakteri. Media kultur selulosa bakteri diekstrak menggunakan kulit nanas $5 \mathrm{~kg}$ dan dicampur dengan air 5 liter dengan menambahkan sebanyak gula $10 \%(\mathrm{~b} / \mathrm{v})$ dan amonium sulfat $0,5 \%$ $(\mathrm{v} / \mathrm{v})$. Tingkat keasaman media diatur dengan menambahkan asam asetat sampai dengan $\mathrm{pH}$ 4,5 serta menambahkan inokulum ke media kultur sebanyak $20 \%(\mathrm{v} / \mathrm{v})$ kemudian diinkubasi pada suhu $30^{\circ} \mathrm{C}$ selama 14 hari. Setelah proses inkubasi, pelikel BC yang dihasilkan pada permukaan medium diambil dan dicuci dengan air sebanyak 5 kali untuk menghilangkan medium residu dan bahan pengotor lainnya. Pelikel $\mathrm{BC}$ direndam dalam larutan $\mathrm{NaOH}$ dengan konsentrasi 1\% selama 24 jam. Setelah 24 jam, pelikel BC dimurnikan dengan pencucian ekstensif dalam air suling pada suhu kamar sampai $\mathrm{pH}$ air menjadi netral.

\subsection{Perlakuan Disintegrasi Mekanis}

Pelikel BC basah yang sudah dimurnikan dipotong menjadi kecil-kecil kemudian dihaluskan menggunakan High Speed Blender (HSB) (Fomac, model ICH-DS7, China) dengan variasi kecepatan 
( $\mathrm{L}=18000 \mathrm{rpm}, \mathrm{M}=21000 \mathrm{rpm}$, dan $\mathrm{H}=26000 \mathrm{rpm}$ ), menambahkan air dengan konsentrasi 0,5\% (b/v). Sampel yang sudah melalui perlakuan dengan HSB kemudian dicetak menggunakan metode casting pada cetakan kaca persegi $(17 \mathrm{~cm}$ x 12,5 cm) dan dikeringkan menggunakan oven (Kirin model KBO250RA, Indonesia) selama 8 jam dengan suhu $60^{\circ} \mathrm{C}$. Sampel film kering dimasukkan ke dalam kantong plastik klip dan disimpan di desikator pada $58 \% \mathrm{RH}$ dan suhu $25^{\circ} \mathrm{C}$ untuk pengujian selanjutnya.

\subsection{Analisis Morfologi}

Morfologi sampel BCF diamati menggunakan SEM (FEI, Inspect-S50) pada 30,00 kV. Sampel ditempatkan pada holder SEM yang dilapisi dengan emas $10 \mathrm{~nm}$ (sputter coater, SC7-620 Emitech).

\subsection{Analisis Struktur}

Kristalinitas BCF dianalisis menggunakan difraktometer XRD (PANalytical X'Pert Pro) menggunakan radiasi $\mathrm{Cu} \mathrm{K} \alpha$ yang disaring dengan nikel $(\lambda=1,54 \AA)$ pada $40 \mathrm{kV}$ dan $30 \mathrm{~mA}$. Sampel dipindai dalam $2 \theta$ sudut dari $10^{\circ}$ hingga $50^{\circ}$ dengan pemindaian tingkat $5 \%$ menit. Crystallinity Index (CI) dan Degree of Crystallinity (\%Cr) dihitung menggunakan metode empiris Segal (peak height) dan metode penyesuaian kurva persamaan 1, 2 [27].

$$
\begin{array}{r}
C I=\frac{I_{(002)}-I_{(a m)}}{I_{(002)}} \times 100 \% \\
\% C I=\frac{I_{(002)}}{I_{(a m)}+I_{(002)}} \times 100 \%
\end{array}
$$

dimana $I_{(002)}$ adalah nilai intensitas puncak maksimum yang sesuai dengan bidang dalam sampel indeks Miller (002) pada sudut $2 \theta$ berkisar diantara $22^{\circ}-23^{\circ}$ yang mewakili bahan kristal. $I_{(a m)}$ adalah nilai intensitas untuk selulosa amorf pada sudut $2 \theta$ berkisar antara $18^{\circ}$ di lembah puncak terendah. Ukuran kristal dihitung menggunakan rumus Scherrer persamaan 3 [1].

$$
\text { Ukuran kristal }=\frac{K \lambda}{W \cos \theta}
$$

dimana $K$ adalah faktor ukuran butir $(0,89), W$ merupakan radian setengah maksimum dengan lebar penuh (FWHM), $\theta$ adalah sudut Bragg, $\lambda$ adalah panjang gelombang radiasi sinar-X $(1,54 \AA)$, dan pusat puncak diperoleh dengan penyesuaian puncak ke fungsi Gauss.

\subsection{Sifat Mekanis}

Sifat mekanis dari BCF diuji dengan pengujian kekuatan tarik (Techno Lab., Indonesia). Sampel dipotong dengan pisau bedah mengikuti standar ASTM D638-V [28]. Sampel BCF ditempatkan pada penjepit mesin kekuatan tarik dengan panjang $26,35 \mathrm{~mm}$ dan ditarik dengan kecepatan 0,025 $\mathrm{mm} / \mathrm{s}$ dan setiap variasi sampel dilakukan 10 kali pengulangan. Kekuatan tarik $(\sigma)$ dihitung dengan rumus persamaan 4

$$
\sigma=\frac{F}{A_{o}}
$$

dimana $\mathrm{F}$ adalah gaya $(\mathrm{N})$ dan $A_{o}$ adalah luas penampang $\left(\mathrm{mm}^{2}\right)$.

\section{Hasil dan Pembahasan}

\subsection{Analisis Morfologi}

Morfologi sebelum dan sesudah perlakuan HSB ditunjukkan pada Gambar 1. BCF dari pelikel terbentuk dari jaringan acak tiga dimensi dari serat nanofiber BC dengan morfologi permukaan halus (Gambar 1a). Sesudah perlakuan HSB (L, M, dan H), BCF menampilkan serat nano fiber yang tersusun secara acak menyebabkan terbentuknya pori yang berukuran mikro maupun nano (Gambar 1b). Akan tetapi, dengan meningkatnya kecepatan pada HSB, menyebabkan serat fiber menjadi terkelupas dan pecah mengarah terbentuknya partikel-partikel yang berukuran mikro maupun nano (Gambar 1c dan 1d). Hal ini diakibatkan karena selama proses HSB terjadi proses mekanis dalam 

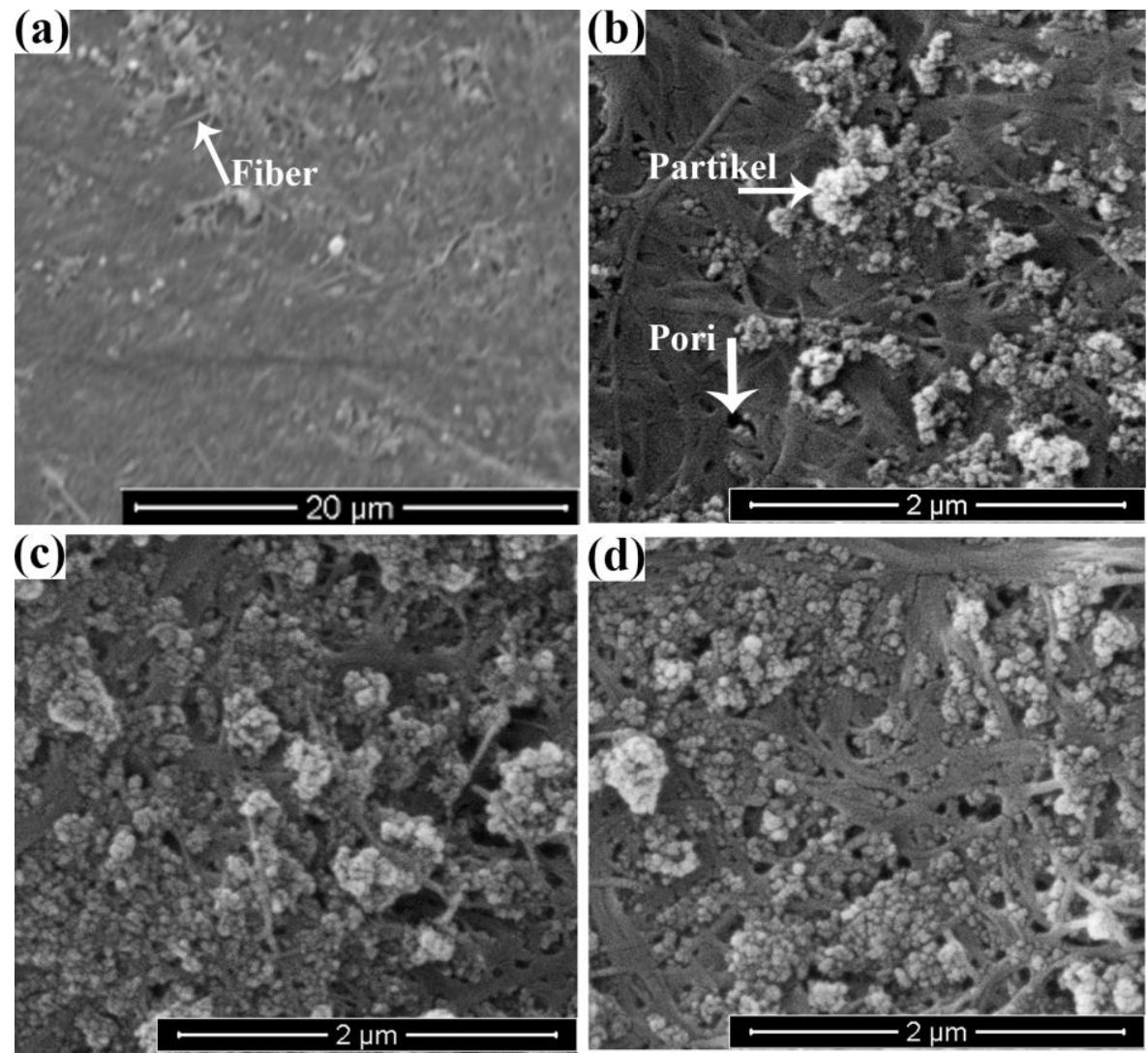

Gambar 1. Morfologi dari BCF; (a) Pelikel, (b) HSB L, (c) HSB M, dan (d) HSB H

tabung HSB berupa gaya potong serat fiber oleh pisau HSB, dan tumbukan antar partikel. Serat fiber BC secara bertahap terpotong dan terpecah dari ikatan hidrogen antara fibril [1], [27]. Oleh karena itu, perlakuan HSB dengan variasi kecepatan dapat mengubah serat menjadi mikro/nano fiber serta partikel dengan penggumpalan dan struktur nano yang berbeda.

\subsection{Analisis Struktur}

Analisis struktur sebelum dan sesudah perlakuan HSB ditunjukkan pada Gambar 2. Difraktogram grafik XRD dari semua sampel menunjukkan tiga puncak difraksi yaitu $14^{\circ}, 16^{\circ}$, dan $22^{\circ}$ berada di wilayah $10^{\circ}-40^{\circ}$ yang ditetapkan untuk bidang kristalografi selulosa. Masing-masing puncak difraksi berhubungan dengan sudut $2 \theta$ difraksi 11̄0, 110, dan 002 [30]. Namun, Puncak difraksi sekitar 16,5 tampak hadir tetapi sangat kecil. Semua sampel BCF sebelum dan sesudah perlakukan memiliki puncak difraksi yang khas pada $2 \theta=14^{\circ}$ dan $22^{\circ}$ yang menunjukkan karakteristik struktur selulosa type I. Dimana, selulosa type I adalah konfigurasi paralel di sudut dan pusat sel satuan sedangkan selulosa type II susunan anti paralel [31], [32]. Hasil ini konsisten dengan data yang dipublikasikan sebelumnya [9], [29-31]. Difraktogram grafik XRD menunjukkan letak puncak difraksi yang sama dari semua $\mathrm{BCF}$ yaitu diantara $22^{\circ}$. Hal ini menunjukkan bahwa perlakuan HSB variasi kecepatan tidak berpengaruh dalam mengubah struktur polimorf BC. Namun, perlakuan HSB dapat menurunkan nilai kristalinitas seperti ditunjukkan pada Tabel 1 . Hasil ini serupa dengan penelitian sebelumnya yang menggunakan gerinding untuk menghasilkan selulosa fiber dari sludge dengan variasi kecepatan mendapatkan hasil yang sama tidak mengubah struktur polimorf [20]. Disamping itu, hal yang sama dilakukan dengan menggunakan perlakuan mekanis terhadap eucalyptus pulp, namun tidak memengaruhi struktur selulosa [36].

Tabel 1 indeks kristalinitas dan derajat kristalinitas sebelum atau sesudah perlakuan HSB menunjukkan penurunan dengan nilai CI BCF pelikel sebesar 83\%, BCF HSB L 81\%, BCF HSB M $78 \%$, dan BCF HSB H 74\% dengan selisih persentase penurunan sebesar $12 \%$. Nilai Cr BCF pelikel sebesar 85\%, BCF HSB L 83\%, BCF HSB M 82\%, dan BCF HSB H 79\%. Nilai Cr yang dihasilkan dari kultur kulit nanas yang didapat sebanding dari produk BC dari kultur Nata de coco adalah $80 \%-$ $86 \%$ [1], [9]. penelitian lainnya menggunakan media nanas untuk menghasilkan $\mathrm{BC}$, dengan nilai CI lebih tinggi yaitu sebesar $86 \%$ [37]. Hasil ini juga lebih tinggi dari selulosa tumbuhan Tabel 1. 


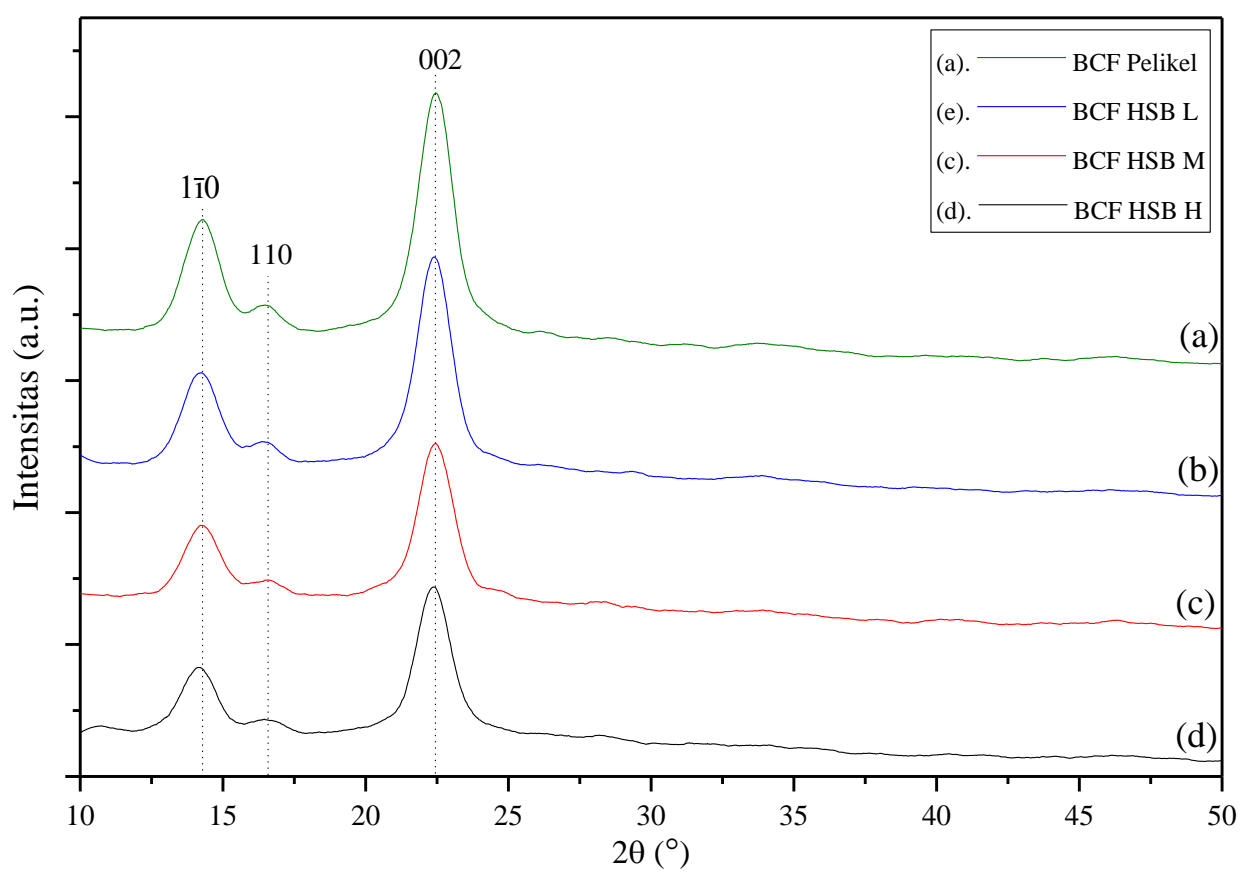

Gambar 2. Difraktogram dari BCF; (a) Pelikel, (b) HSB L, (c) HSB M, dan (d) HSB H

Tabel 1. Indeks kristalinitas, derajat kristalinitas, ukuran kristal dari BCF sebelum dan sesudah perlakuan HSB

\begin{tabular}{lllll}
\hline Selulosa BC & $\begin{array}{l}\text { Indeks } \\
\text { Kristalinitas } \\
(\%)\end{array}$ & $\begin{array}{l}\text { Derajat } \\
\text { Kristalinitas } \\
(\%)\end{array}$ & Ukuran Kristal (nm) & Referensi \\
\hline BCF (pelikel) & 83 & 85 & 1,05 & Studi ini \\
BCF HSB L & 80 & 83 & 1,04 & Studi ini \\
BCF HSB M & 79 & 82 & 0,99 & Studi ini \\
BCF HSB H & 74 & 79 & 1,00 & Studi ini \\
Nata de coco & 80 & - & 4,4 & {$[9],[33]$} \\
& 86 & - & 0,050 & {$[1]$} \\
Selulosa & & & & \\
Tumbuhan & & 70,7 & 14,3 & {$[25]$} \\
Mendong & 58,6 & 77 & 5,4 & {$[34]$} \\
Flax & 70 & 78,7 & $5-7$ & {$[35],[36]$} \\
Kapas & 85,3 & & & \\
\hline
\end{tabular}

Hal ini membuktikan bahwa kemurnian selulosa yang dihasilkan dari bakteri memiliki kristalinitas yang tinggi. Hasil CI yang didapatkan serupa dengan penelitian sebelumnya yakni produksi cellulose nanofibers (CNFs) dari eucalyptus pulp menggunakan grinding yang menunjukkan penurunan CI [36]. Ukuran kristal sebesar BCF pelikel sebesar 1,05 nm, BCF HSB L 1,04 nm, BCF HSB M 0,99 $\mathrm{nm}$, dan BCF HSB H 1,00 nm. Hasil ini juga serupa dengan penelitian sebelumnya yang memberikan perlakuan mekanis homogenisasi dengan variasi cycles dan menunjukkan penurunan ukuran kristal selulosa [1]. Penurunan kristalinitas disebabkan karena pada proses HSB terjadi gaya potong antar serat, pisau blinder, gaya gesekan antar partikel, dan tumbukan antar partikel yang dapat memecahkan jaringan ikatan selulosa atau kerusakan struktur kristal dengan meningkatnya kecepatan HSB.

\subsection{Sifat Mekanis}

Kurva tegangan-regangan dari sampel BCF sebelum dan sesudah perlakuan HSB ditunjukkan pada Gambar 3. Secara umum, kekuatan tarik BCF mengalami penurunan sesudah mengalami perlakuan HSB (L, M, dan H). Nilai kekuatan tarik BCF pelikel sebesar 308,17 MPa menurun menjadi 159,16 MPa setelah perlakuan HSB L dengan selisih persentase penurunan sebesar $94 \%$. Namun, sampel BCF HSB M meningkat sebesar 187,29 MPa dan turun kembali menjadi 171,87 MPa BCF HSB H. Meningkatnya kekuatan tarik pada HSB M disebabkan partikel yang terbentuk sangat banyak sehingga ikatan permukaan antar fiber dan partikel semakin kuat. Hasil yang diperoleh konsisten 


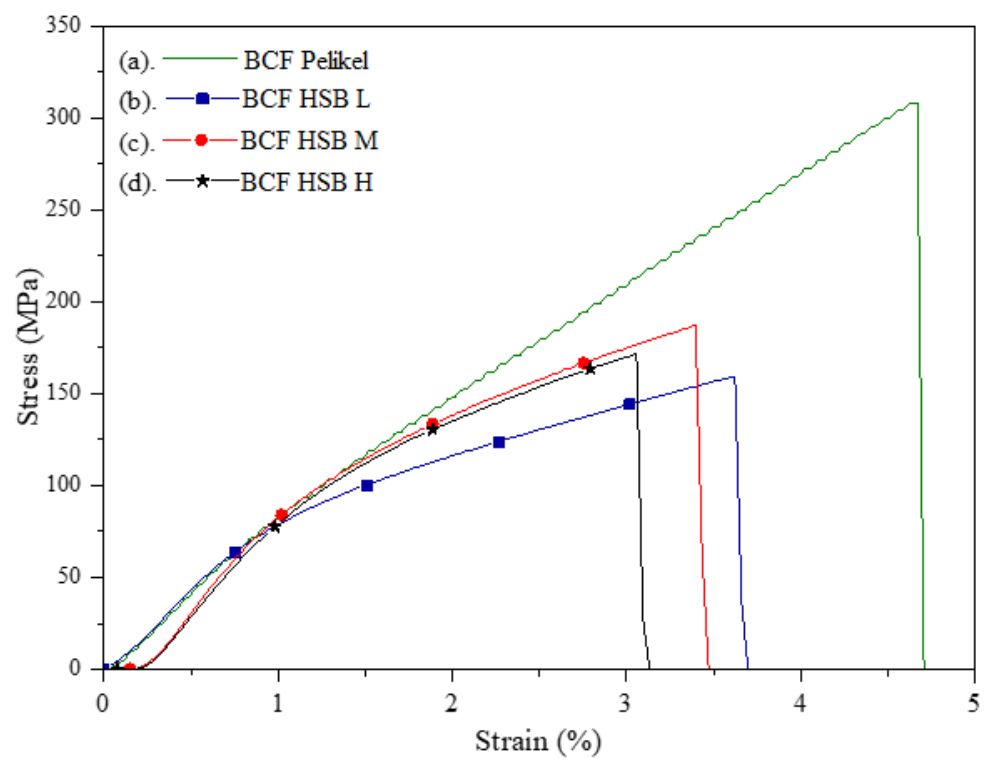

Gambar 3. Sifat Mekanis dari BCF; (a) Pelikel, (b) HSB L, (c) HSB M, dan (d) HSB H

dengan morfologi HSB M yang ditunjukkan pada Gambar 1c. Namun, HSB H menurun disebabkan serat fiber mulai terkelupas sehingga membesarnya pori yang menimbulkan berkurangnya ikatan permukaan antar serat dan partikel yang ditunjukkan pada Gambar 1d. Hasil ini sebanding dengan penelitian sebelumnya dimana kekuatan tarik film BC berkisar antara $200 \mathrm{MPa}-300 \mathrm{MPa}$ dan perpanjangan berkisar antara 1,5\% - 2,0\% [37]. Nilai perpanjangan pada setiap sampel mengalami penurunan sebagaimana ditunjukkan pada Gambar 3. Nilai perpanjangan BCF pelikel sebesar 4,67\% menurun menjadi 3,62\% untuk sampel BCF HSB L, sampel BCF HSB M sebesar 3,4\%, dan sampel BCF HSB H sebesar 3,06\%. Dengan demikian, perlakuan HSB dengan variasi kecepatan terhadap BC secara unik dapat mengubah struktur jaringan serat, interaksi antar ikatan hidrogen, dan melepas bundel dari pengotor ataupun antar serat BCF. Interaksi inilah yang dapat meningkatkan dan menurunkan kekuatan tarik BCF dengan memperkuat dan melemahkan konektivitas antar fibril yang terbentuk pada jaringan selulosa [36], [37]. Pada perlakuan HSB menimbulkan penurunan ikatan antar serat sehingga kekuatan tarik menurun.

\section{Kesimpulan}

Analisis struktur dan sifat mekanis BCF dengan variasi kecepatan pada HSB telah dilakukan. Secara keseluruhan perlakuan HSB memengaruhi karakter BCF. Perlakuan HSB menghasilkan perubahan morfologi BCF dimana serat $\mathrm{BC}$ menjadi terkelupas mengarah terbentuk partikel dan menghasilkan film berpori. Peningkatan kecepatan HSB telah berhasil menurunkan kristalinitas BCF sebesar 12\% disertai dengan penurunan kekuatan tarik sebesar $94 \%$, yang memegang peranan penting dalam proses disintegrasi pada BCF. Struktur BCF setelah perlakuan menghasilkan pori dan partikel sehingga menyediakan udara untuk berdifusi ke dalam film. Di masa yang akan datang dengan rekayasa struktur BCF ini dapat dikembangkan menjadi suatu membran untuk aplikasi filter dan maupun untuk sensor.

\section{Ucapan Terima Kasih}

Ucapan terima kasih disampaikan kepada Universitas Negeri Malang melalui kegiatan penelitian dana PNBP no kontrak 2.3.147/UN32.14/LT/2018.

\section{Daftar Rujukan}

[1] N. Kawee, N. T. Lam, dan P. Sukyai, "Homogenous isolation of individualized bacterial nanofibrillated cellulose by high pressure homogenization," Carbohydr. Polym., vol. 179, hal. 394-401, 2017.

[2] A. R. P. Figueiredo, C. Vilela, C. P. Neto, A. J. D. Silvestre, dan C. S. R. Freire, "Bacterial Cellulose-Based Nanocomposites: Roadmap for Innovative Materials," in Nanocellulose Polymer Nanocomposites: Fundamentals and Applications, V. K. Thakur, Ed. Beverly: 
Scrivener Publishing LLC, hal17-64, 2015.

[3] N. Farahbakhsh, R. A. Venditti, dan J. S. Jur, "Mechanical and thermal investigation of thermoplastic nanocomposite films fabricated using micro- and nano-sized fillers from recycled cotton T-shirts," Cellulose, vol. 21, no. 4, hal. 2743-2755, 2014.

[4] N. Tka, M. Jabli, T. A. Saleh, dan G. A. Salman, "Amines modified fibers obtained from natural Populus tremula and their rapid biosorption of Acid Blue 25," J. Mol. Liq., vol. 250, hal. 423-432, 2018.

[5] N. Siddiqui, R. H. Mills, D. J. Gardner, dan D. Bousfield, "Production and characterization of cellulose nanofibers from wood pulp," J. Adhes. Sci. Technol., vol. 25, no. 6-7, hal. 709-721, 2010.

[6] M. Fan, D. Dai, dan A. Yang, "High strength natural fiber composite: Defibrillation and its mechanisms of nano Cellulose hemp fibers," Int. J. Polym. Mater. Polym. Biomater., vol. 60, no. 13, hal. 1026-1040, 2011.

[7] P. Lestari, N. Elfrida, A. Suryani, dan Y. Suryadi, "Study on the Production of Bacterial Cellulose from Acetobacter Xylinum Using Agro - Waste," Jordan J. Biol. Sci., vol. 7, no. 1, hal. 75-80, 2014.

[8] A. R. P. Figueiredo, A. J. D. Silvestre, C. P. Neto, dan C. S. R. Freire, "In situ synthesis of bacterial cellulose/polycaprolactone blends for hot pressing nanocomposite films production," Carbohydr. Polym., vol. 132, hal. 400-408, 2015.

[9] N. Halib, M. C. I. M. Amin, dan I. Ahmad, "Physicochemical Properties and Characterization of Nata de Coco from Local Food Industries as a Source of Cellulose," Sains Malaysiana, vol. 41, no. 2, hal. 205-211, 2012.

[10] L. Nuryati dan B. Waryonto, Statistik Pertanian Agricultural Statistics. Jakarta: pusdatin, hal. 1400, 2016.

[11] A. Retegi dkk., "Bacterial cellulose films with controlled microstructure-mechanical property relationships," Cellulose, vol. 17, no. 3, hal. 661-669, 2010.

[12] H. Abral, V. Lawrensius, D. Handayani, dan E. Sugiarti, "Preparation of nano-sized particles from bacterial cellulose using ultrasonication and their characterization," Carbohydr. Polym., vol. 191, hal. 161-167, 2018.

[13] T. Thi, J. Sugiyama, dan V. Bulone, "Bacterial Cellulose-based Biomimetic Composites," in Biopolymers, hal. 1-26, 2010.

[14] A. Ashjaran, M. E. Yazdanshenas, A. Rashidi, R. Khajavi, dan A. Rezaee, "Overview of bio nanofabric from bacterial cellulose," J. Text. Inst., vol. 104, no. 2, hal. 121-131, 2013.

[15] S. Ummartyotin, J. Juntaro, M. Sain, dan H. Manuspiya, "Development of transparent bacterial cellulose nanocomposite film as substrate for flexible organic light emitting diode (OLED) display," Ind. Crops Prod., vol. 35, no. 1, hal. 92-97, 2012.

[16] Y. Zheng dkk., "Synthesis of flexible magnetic nanohybrid based on bacterial cellulose under ultrasonic irradiation," Mater. Sci. Eng. C, vol. 33, no. 4, hal. 2407-2412, 2013.

[17] D. M. Panaitescu, A. N. Frone, dan I. Chiulan, "Nanostructured biocomposites from aliphatic polyesters and bacterial cellulose," Ind. Crops Prod., vol. 93, hal. 251-266, 2016.

[18] E. Trovatti dkk., "Novel bacterial cellulose-acrylic resin nanocomposites," Compos. Sci. Technol., vol. 70, no. 7, hal. 1148-1153, 2010.

[19] O. Nechyporchuk, M. N. Belgacem, dan J. Bras, "Production of cellulose nanofibrils: A review of recent advances," Ind. Crops Prod., vol. 93, hal. 2-25, 2016.

[20] M. Jonoobi, A. P. Mathew, dan K. Oksman, "Producing low-cost cellulose nanofiber from sludge as new source of raw materials," Ind. Crops Prod., vol. 40, no. 1, hal. 232-238, 2012.

[21] A. Chakraborty, M. Sain, dan M. Kortschot, "Cellulose microfibrils: A novel method of preparation using high shear refining and cryocrushing," Holzforschung, vol. 59, no. 1, hal. 102-107, 2005.

[22] A. Ferrer, I. Filpponen, A. Rodríguez, J. Laine, dan O. J. Rojas, "Valorization of residual Empty Palm Fruit Bunch Fibers (EPFBF) by microfluidization: Production of nanofibrillated cellulose and EPFBF nanopaper," Bioresour. Technol., vol. 125, hal. 249-255, 2012.

[23] V. S. Karande, A. K. Bharimalla, G. B. Hadge, S. T. Mhaske, dan N. Vigneshwaran, "Nanofibrillation of cotton fibers by disc refiner and its characterization," Fibers Polym., vol. 12, no. 3, pp. 399-404, 2011. 
[24] D. Lin, R. Li, P. Lopez-Sanchez, dan Z. Li, "Physical properties of bacterial cellulose aqueous suspensions treated by high pressure homogenizer," Food Hydrocoll., vol. 44, hal. 435-442, 2015.

[25] K. Saelee, N. Yingkamhaeng, T. Nimchua, dan P. Sukyai, "An environmentally friendly xylanase-assisted pretreatment for cellulose nanofibrils isolation from sugarcane bagasse by high-pressure homogenization," Ind. Crops Prod., vol. 82, hal. 149-160, 2016.

[26] M. Li, L. J. Wang, D. Li, Y. L. Cheng, dan B. Adhikari, "Preparation and characterization of cellulose nanofibers from de-pectinated sugar beet pulp," Carbohydr. Polym., vol. 102, no. 1, hal. 136-143, 2014.

[27] H. Suryanto, E. Marsyahyo, Y. S. Irawan, dan R. Soenoko, "Effect of Alkali Treatment on Crystalline Structure of Cellulose Fiber from Mendong (Fimbristylis globulosa) Straw," Key Eng. Mater., vol. 594-595, hal. 720-724, 2013.

[28] M. Jonoobi, J. Harun, A. P. Mathew, dan K. Oksman, "Mechanical properties of cellulose nanofiber (CNF) reinforced polylactic acid (PLA) prepared by twin screw extrusion," Compos. Sci. Technol., vol. 70, no. 12, hal. 1742-1747, 2010.

[29] J. Zhao, W. Zhang, X. Zhang, X. Zhang, C. Lu, dan Y. Deng, "Extraction of cellulose nanofibrils from dry softwood pulp using high shear homogenization," Carbohydr. Polym., vol. 97, no. 2, hal. 695-702, 2013.

[30] A. T. Vicente dkk., "Optoelectronics dan Bio Devices on Paper Powered by Solar Cells," in Nanostructured Solar Cells, N. Das, Ed. Caparica: InTech, hal. 1-716, 2017.

[31] S. Nam, A. D. French, B. D. Condon, dan M. Concha, "Segal crystallinity index revisited by the simulation of X-ray diffraction patterns of cotton cellulose I $\beta$ and cellulose II," Carbohydr. Polym., vol. 135, hal. 1-9, 2016.

[32] A. C. Corrêa, E. M. de Teixeira, L. A. Pessan, dan L. H. C. Mattoso, "Cellulose nanofibers from curaua fibers," Cellulose, vol. 17, no. 6, hal. 1183-1192, 2010.

[33] Y. Wan dkk., "Preparation and characterization of bacterial cellulose/heparin hybrid nanofiber for potential vascular tissue engineering scaffolds," Polym. Adv. Technol., vol. 22, no. 12, hal. 2643-2648, 2011.

[34] H. H. Chen, L. C. Chen, H. C. Huang, and S. Bin Lin, "In situ modification of bacterial cellulose nanostructure by adding CMC during the growth of Gluconacetobacter xylinus," Cellulose, vol. 18, no. 6, hal. 1573-1583, 2011.

[35] P. Lv dkk., "Copper nanoparticles-sputtered bacterial cellulose nanocomposites displaying enhanced electromagnetic shielding, thermal, conduction, and mechanical properties," Cellulose, vol. 23, no. 5, hal. 3117-3127, 2016.

[36] Q. Q. Wang, J. Y. Zhu, R. Gleisner, T. A. Kuster, U. Baxa, dan S. E. McNeil, "Morphological development of cellulose fibrils of a bleached eucalyptus pulp by mechanical fibrillation," Cellulose, vol. 19, no. 5, hal. 1631-1643, 2012.

[37] A. Retegi dkk., "Bacterial cellulose films with controlled microstructure-mechanical property relationships," Cellulose, vol. 17, no. 3, hal. 661-669, 2010.

[38] J. Gong, J. Li, J. Xu, Z. Xiang, dan L. Mo, "Research on cellulose nanocrystals produced from cellulose sources with various polymorphs," $R S C A d v$., vol. 7, no. 53, hal. 33486-33493, 2017.

[39] A. Bismarck, S. Mishra, dan T. Lampke, "Plant Fibers as Reinforcement for Green Composites," in Natural Fibers, Biopolymers, and Biocomposites, Taylor \& Francis, 2005, hal. $1-72$.

[40] D. V. Parikh, D. P. Thibodeaux, dan B. Condon, "X-ray Crystallinity of Bleached and Crosslinked Cottons," Text. Res. J., vol. 77, no. 8, hal. 612-616, 2007.

[41] P. Gatenholm dan D. Klemm, "B acterial Nanocellulose as a Renewable Material for Biomedical Applications," vol. 35, no. March, hal. 208-214, 2010.

[42] M. S. Dayal dan J. M. Catchmark, "Mechanical and structural property analysis of bacterial cellulose composites," Carbohydr. Polym., vol. 144, hal. 447-453, 2016. 